\title{
Class, Race, Credibility, and Authenticity within the Hip-Hop Music Genre
}

\author{
Matthew R. Hodgman \\ Dept. of General Education, Goodwin College \\ 1 Riverside Drive, East Hartford, CT, 06118, USA \\ Tel: 1-860-528-4111 E-mail: mhodgman@goodwin.edu \\ Doi:10.5296/jsr.v4i2.4503 URL: http://dx.doi.org/10.5296/jsr.v4i2.4503
}

\begin{abstract}
After its advent in the 1970s, the rap music genre was represented almost exclusively by male black artists who honestly and realistically embodied a poor urban image. Images of black urban poverty in music videos and rap lyrics were consistently used by black artists to emphasize and authenticate who they were and where they came from. With the upsurge of white rap acts starting in the early 90 s and continuing through the early $21^{\text {st }}$ century, the means by which rap authenticity is measured have been permanently renegotiated. Before the emergence of white rappers, race was the primary signifier of rapper authenticity. After the success of white rappers such as Eminem new parameters of what constitute credibility and authenticity in the rap genre have been forged. This article discusses the significance of the continued presence of white rappers in hip-hop in terms of class and race in relation to artistic credibility within the rap genre. On a larger scale, this article considers questions related to cultural interloping upon a racially concentrated art form. It is concluded that class has generally emerged as the premier indicator or variable of authenticity throughout rap.
\end{abstract}

Keywords: rap music, hip-hop music, Eminem, cultural studies, class studies

\section{Introduction}

The "game" or musical sub-genre of rap began in the mid-1970's in the ghettos of New York City. Housed within the greater hip-hop movement, the essence of this new art form was visible at city block parties, schoolyards, and parks where a fresh fusion of musical beats, dance, slang, and fashion would eventually become an international phenomenon. Many founding artists such as Grandmaster Flash pinpoint the birthplace of rap as the Bronx, New York City, 1974, known for its disproportionate share of ghetto slums and primarily lower class black and Latino population (Perkins 5-6). It is this distinct location, and the rappers that emerged from it, that would set the standards for judging the quality and authenticity of rappers to come. Central to the argument over what constitutes an authentic rapper lies the issue and question of "being real," a question that has serious implications for the acceptance of a rapper into the hip-hop community. The concept of "the real" has emerged to explain the 
importance of racially and spatially based signifiers to rapper authenticity and credibility. In the introduction to his text, The 'Hood Comes First: Race, Space, and Place in Rap and Hip-Hop, Cultural theorist Murray Forman describes the racial-spatial dichotomy of "the real" and its importance in deciphering authenticity within hip-hop. He explains:

combined

In most cases it stands as an ill-defined expression referring to the

aspects of racial essentialism, spatial location, and a basic adherence to

principles of the hip-hop culture[...]Yet the boundaries between real or authentic cultural identities and those deemed inauthentic are carefully

policed

real"

cultural

from within the hip-hop culture, and the delineations that define "the are taken with deadly seriousness by those who ascribe to hip-hop's influences. (xviii)

Clearly, the difference between what is and what is not "real" is at the crux of rap authenticity configuration. Forman shows us that being "real" in the world of rap involves possessing "real" racial characteristics in addition to claiming a "real" spatial location as one's birthplace or childhood dwelling. In relation to the dynamics of the Bronx, as the authentic birthplace of rap, this translates to the idea that an authentic rapper must be of black or Latino descent and hail from an urban ghetto, or some other urban space of economic poverty and underclass living. (I use the term "ghetto" in accordance with the U.S. Department of Housing and Urban Development definition which is, "an area in which the overall census tract poverty rate is greater than 40 percent") (Forman 55). These signifiers represent the racial and spatial roots of rap and hip-hop. Implicit in this representation is the understanding that blackness and Latinoness are inextricably linked to urban class poverty, which positions race as the primary indicator of rapper authenticity. This connection between race and class has long defined the authentic underpinnings of rap music. Since black has become socially equivalent to being lower class, blacks have little difficulty in gaining street and critic credibility. Forman explains in Althusserian terms: "For black artists, the projection of ghetto associations is less difficult and less contentious, since the dominant social perspective "always already" interpellates black youths, especially males, as ghetto citizens, if not ghetto thugs" (62).

For many years after the advent of rap, the genre was inhabited overwhelmingly by male black artists who were able to honestly project and identify with the poor urban minority image. Images of black urban poverty in music videos and lyrics describing such an existence were consistently used by black artists to emphasize and authenticate who they were and what location they came from. Murray details, "In rap and hip-hop, the denotative and connotative representations, through both language and images of the urban terrain, are discursively rendered describing and narrating a perceived social reality that is further 
invested with values of authenticity" (9). In her award winning work Black Noise, Tricia Rose further articulates the importance of identifying with a lower class urban space through the construction of music videos. She explains:

Rap video has also developed its own style and its own genre conventions.

These conventions visualize hip-hop style and usually affirm rap's

primary

thematic concerns: identity and location. Over most of its brief history,

rap

local

video themes have repeatedly converged around the depiction of the neighborhood and the local posse, crew, or support system. Nothing is

more

central to rap's music video narratives than situating the rapper in his or

her

buses,

inner-city

milieu and among one's crew or posse...rap music videos are set on subways, in abandoned buildings, and almost always in black urban

locations. (9-10)

Thus, early rappers valorized their race and concurrently the class-based location of rap, which meant talking about and showing ghettos and other underclass images of the urban terrain. This also took the form of talking about fractured families, drug abuse, violent crime, debt, unemployment, and educational disenfranchisement as was the case in Grandmaster Flash's pioneering 1982 track "The Message" (Forman 88). These were some of the descriptors that linked class to the authentic space from which rappers and rap itself originated.

\section{White Rappers and the New Construction of Rap Authenticity}

However, the tightly linked signifiers of race, class, and gender would be tested and problematized with the increasing commercial visibility and viability of white rappers in the early 90's through the next millennium. How would the rap community judge white rappers, who cannot utilize racial signifiers to establish authenticity? Would the measuring stick of rap credibility need to be modified or thrown out completely? Would white rappers ever be viewed as authentic? In light of rap sensations such as The Beastie Boys, House of Pain, and Eminem, what would happen to the race-class dichotomy that has previously determined rapper credibility? Clearly, the "game" of rap has been restructured to include these artists and other white artists. The result is that race-based component of authentic rap determination has dropped out of the equation. This leads to a proposal that class, as it relates to authentic spaces of poverty, has displaced race as the primary signifier of rap authenticity. In this new configuration, white rappers who cannot claim inherent racial blackness must borrow from, mimic, or actually hail from the lower class black urban space that rap arose from without losing themselves in order to be authentic and ultimately successful artists. 


\section{Macrothink}

\subsection{Eminem}

There are numerous white rap successes and failures that illustrate my point. Perhaps the best example of a white rapper who has gained credibility and respect through class is Eminem. Selling 1.7 million copies of his sophomore major label album The Marshall Mathers LP (2000, Aftermath/Interscope) in its debut week, Eminem certainly is no stranger to success. However, he is also quite familiar with the trappings and tribulations of abject poverty. In terms of class pedigree, Eminem is an authentic product. The details of his lower class upbringing are articulated by author Martin Huxley in his work entitled Eminem: Crossing the Line. Eminem or Marshall Mathers III was born to a single teenage mother on welfare and his father left him when he was a baby. At the age of 12, he moved to a predominantly black neighborhood on the east side of Detroit with his mother and his newborn half-brother Nathan. Huxley further describes Eminem's childhood poverty and how it provoked him to write rap through stating, "Growing up in an economically disadvantaged area brought Marshall face-to-face with the randomness of urban violence, much of which carried racial undertones. He began writing and recording his own raps at the age of thirteen, and his budding rhyme abilities boosted his confidence, helping him to come out of his shell and make new friends" (10). Many of Eminem's raps were credible stories about his ongoing economic struggles as evidenced in "Never 2 Far" off his first album Infinite and "Rock Bottom" off his Slim Shady LP (1999, Aftermath/Interscope). In "Rock Bottom" Eminem talks about a time in his life where he was evicted from the house he was renting with one of his friends in Detroit. The eviction prompted him to swallow numerous codeine tablets, and after a purging session in the bathroom, he wrote the track. His economic situation was so dismal that he feared the only way to release the pain of poverty was suicide (Eminem: Angry Blonde 18-19). The rap chants:

Verse 1

I feel like I'm walking a tight rope, without a circus net,

Popping Percocets, I'm a nervous wreck,

I deserve respect; but I work a sweat for this worthless check,

'Bout to burst this tech, at somebody to reverse this debt.

Minimum wage got my adrenaline caged,

Full of venom and rage...

Verse 2:

My life is full of empty promises,

And broken dreams,

'Hopin things look up,

But there ain't no job openings,

I feel discouraged, hungry, malnourished,

Living in this house with no furnace, unfurnished,

And I'm sick of working dead-end jobs with lame pay,

And I'm tired of being hired and fired the same day... 


\section{Chorus:}

That's rock bottom,

When this life makes you mad enough to kill,

That's rock bottom,

When you want something bad enough to steal,

That's rock bottom,

When you feel you have had it up to here,

'Cause you mad enough to scream but you sand enough to tear.

His lyrics embody the downtrodden working-class community within Detroit where he was raised. Debt, hunger, and empty promises are the descriptors of his disadvantaged past. The authenticity of Eminem's art lies in his ability to honestly represent a black urban lower class space. The roots of his platinum hair may be questionable, but his underclass upbringing is not. Eminem is the quintessential example of rap's move from race-based authenticity toward class-based authenticity. When skin color can no longer be a uniform criterion, class steps forward as the new standard in rap authenticity.

Perhaps 8 Mile (2003, Universal), the film based on Eminem's life, demonstrates this point to a greater degree. Rabbit, the image of Eminem, is trying to rap his way out of the Detroit area slums and into a better life. Early on, a friend builds up his confidence by telling him, "Once they hear you, it won't matter what color you are." The film builds to a scene where Rabbit verbally battles a black rapper named Papa Doc. Rabbit, who lives with his mother in a trailer, hails from working-class poverty. He is a product of the class-based space of rap's New York City origins. Rabbit takes pride in exposing the class background of Papa Doc, who is supposedly a more authentic rapper because of his congruently black, and thus poor background. Rabbit reveals that Papa Doc attended a private school, has parents that are not divorced, and is really named Clarence. Thus, Papa Doc is from the middle-class, a revelation that leaves "Clarence" speechless. Rabbit walks away from the lyrical match as the clear winner. The battle clearly pits class-based authenticity (Rabbit) against race-based authenticity (Papa Doc) with Rabbit winning out and thus declaring class-based authenticity as the new standard to judge all rappers by.

\subsection{Bubba Sparxxx and Snow}

There are two other good examples of class-based authentic white rappers, one of which does not even hail from an urban locale. I'm talking about Bubba Sparxxx and Snow. Both of these white lyricists quickly gained popularity through catchy debut tracks and multi-platinum sales, but they were able to gain credibility through their true-to-life status as members of the lower class. Snow has urban roots where Bubba is a country dweller. Known for his 1993 break through hit "Informer" off his debut album 12 Inches of Snow (1993, Atlantic), Snow's class roots are deeply ensconced within a lower class mixed Irish-Caribbean culture. Born and raised in the black ghettos of Toronto, Canada, the Irish-Jamaican Snow spent his early childhood years listening to the rap creations of black underclass musicians in his Toronto neighborhood. It was there that he would learn to fuse rap with the flows and rhythms native to his Jamaican culture. Snow's fast spoken reggae-rap style would evolve into the hallmark 
of his artistry. His success and acceptance into the rap community was predicated upon his authentic lower class roots and identification with black-dominated reggae culture. As Murray Forman explains, such a connection rendered Snow an authentic artist. Forman states: In Canada, Toronto's successful dance-hall reggae rapper Snow represents an

working-class

example of the meeting between Irish and black Caribbean a cultures. One outcome of the trend is that the conflation of the ghetto as within privileged sociospatial site and an idealized image of black authenticity hip-hop discourse has continually threatened to override other possible images

one's racial of lived cultural space among the hip-hop generation, regardless of identity. (61)

As Forman delineates, Snow's authentic lower class upbringing has displaced his racial identity in the hip-hop community. Snow's credibility is further enhanced by his connection to reggae, a typically black inhabited form of music. This combination has led critics to support Snow as an authentic rapper. His audiences can believe him when he claims:

But in the in an' the out of a dance them they say where you come from, People them say you come from Jamaica,

But me born an' raised in the ghetto that's the one I want you to know, Pure black people mon that's all I mon know.

Yeah me shoes are tear up an' me toes used to show,

Where me born in on the one Toronto...("Informer" Atlantic 1993)

Pop-journalist Armond White also agrees that the class identified urban Jamaican style allows Snow to be seen as an artist with "rootsy credibility" (202). Snow has not produced a rap record in the new millennium, but his multi-platinum success in the 90's has proven to audiences that a class authentic artist is an overall authentic artist bound to be successful in some capacity.

The power of the urban class-based signifier to establish rapper authenticity is apparent, but in the case of Bubba Sparxx, so are rural class-based signifiers. Southern white rapper Bubba Sparxxx has proven that the class-based signifiers of poverty and lower class standing apply to non-urban settings as well. The critical acclaim of Bubba's first album Dark Days, Bright Nights (2002, Interscope) can be credited to the fact that he is able to authentically identify with a poor working-class space without losing track of who he is, regardless of his space's non-urban locale. In an interview with Much Music, Bubba describes the conditions he grew up in:

I didn't have much access to it [music] because I grew up so far out into the 
minutes

neighbor

black

country. We didn't have cable TV. I grew up on a dirt road about 15 north of LaGrange [Georgia]. It was extremely rural. My closest was between a half-mile and a mile away. My closest neighbor was a kid and that was actually my first exposure to rap. (Much Music.com)

Bubba sets up his rural existence to play to skeptics who will be eager to put down another white rapper trying to commandeer a black man's art. By linking himself to the extreme rural South and to a black neighbor, he describes a lower class scenario that is also associated with near-by racial authenticity. Class, however, is the primary signifier here. Further details about Bubba's family make that clear. In the Much Music interview, we learn that Bubba was the youngest of 5 children, and the only child who was not from a previous marriage. His mother was a grocery store cashier and his father was a meat cutter who moonlighted as a school bus driver and a Lance Potato Chip truck driver (1). Bubba's family's working-class status allows his rap to be viewed as authentic despite being housed in rural Georgia. His debut album went gold in its first six months to prove it. He is currently in the studio working on his sophomore record yet to be titled. Bubba is part of a wave white rappers like Eminem and Snow that have solidified authentic status due to their authentic lower class affiliations. However, there have been numerous white rappers and rap acts that have tried to gain acceptance into the rap community without authentic sociospatial connections. It is these rappers that must successfully mimic such a low class aesthetic or risk economic failure and eternal embarrassment.

\subsection{Vanilla Ice}

The most classic example of class mimicry gone wrong is associated with early 90's rapper Vanilla Ice. He is the poster boy for the consequences of the need to attain class-based spatial authenticity. With the release of his debut album To the Extreme in 1990 (SBK), Vanilla Ice was feeling pretty good. His album had almost instantly gone platinum and he was selling out major venues across the U.S. Despite eventually selling seven million plus copies of his rookie record, the name Vanilla Ice will never be synonymous with respect or authenticity. After many claims to growing up in a poor Miami neighborhood, Vanilla, or Robert Van Winkle, was exposed for committing the ultimate rap taboo, ostentatiously feigning a lower class background. In attempts to overcome his own whiteness, Vanilla Ice constructed a past for himself that was supposedly full of gang violence, ghetto dwelling, and overall destitution. He told Stephen Holden of the New York Times that "he 'grew up in the ghetto,' comes from a broken home, hung out mainly with blacks while attending the same Miami high school as Luther Campbell of 2 Live Crew, and was nearly killed in a gang fight" (Rose 11). He even faked reggae rap on the song "Rostaman" to keep black ingenuity marginalized (White 199). Nothing could be further from the truth. Murray Forman contests that Vanilla attempted to rewrite his own middle-class biography and publish it in the early 90's in order to establish false ghetto credentials and reinforce his popular viability (61). He fooled no one. He was immediately revealed and snubbed out by family members and friends 
who knew him from his childhood days in an affluent Dallas suburb. He had no chance to rectify the situation since his mimicry was so egregious. Vanilla had nothing going for him accept the novelty of his skin color. The rap community was outraged and disgraced by a "white boy" who showed no subtlety or respect in feigning a lower class urban existence. Murray Forman describes the pitiful deception:

It is this deception and not solely the fact of his whiteness, that has

made

to be

hard-

Vanilla Ice the symbolic antithesis of ghetto authenticity and caused him

vilified. His skin color was undoubtedly an inconvenience among the

core hip-hop aficionados whose own preconceptions about authenticity

and

His

were

ghetto reality blinded them to the possibilities of white talent in the field.

arrogant attitude and deliberate deception - not keeping it real at all -

unconscionable in the eyes of the collective hip-hop nation. (61)

The emphasis in this assessment is on the deliberate nature of Vanilla Ice's deceit. Such a feigning of the lower class does not immediately discredit a white artist by my standards. In Vanilla's case, an artist was proven inauthentic because he was unable to mimic the lower class black urban space without losing himself in the process. Vanilla Ice did not try and nuance his false class status. He did so with arrogance, perhaps even malice and most importantly, without any respect for himself or the community he was mocking. Because of this disgraceful behavior, Vanilla Ice was unable to gain an authentic label that may have been his despite his racial disadvantage. More importantly, Vanilla Ice shows us that class, not racial status, is the primary determinant of rapper authenticity.

\subsection{Marky Mark}

There are no other false identity examples as brash as Vanilla Ice, but there is another high profile example of failed lower class mimicry, namely the white rapper Marky Mark. Marky Mark a.k.a. Mark Wahlberg began and shortly ended his rap career in the early ' 90 's. His debut release Music for the People was initially greeted with enthusiastic sales and listener response as it placed in the UK top 20, but as time went on, Mark's credibility to listeners and critics alike sank along with his music career. Mark hailed from a lower middle-class suburb of Boston. His neighborhood was a far cry from affluence, but it was not the lower class murder-filled ghetto that he verbally made it out to be. Mark may have had a shot at credibility if he would have only claimed that he was not overly wealthy. However, Mark felt the need to project an image of his neighborhood as far more "ghetto" than it actually was. He did so in a blatant and compromising fashion. In the title track off his album You Gotta Believe, Mark states the following:

Steady ready to wreck shop,

Another rough kid from the streets,

Don't sleep on the crew, 'cuz if we roll through, 
You'll get hit up, watch blood spit up. (1992, Interscope)

Furthermore, in the title track off his collaboration album with rapper Prince Ital Joe entitled "Life in the Streets," Mark voices the following:

Yo I grew up rough in the streets of Boston Mass.,

Lived real ruthless, a wild kid, out to get a bid.

Hard and mean at 16, livin' like a beam, theme,

Out scheming for the green,

Quick to kill, I gets ill, I make ya blood spill,

Cuz statistics show that kids with no dough,

Ain't got no chance, got nowhere to go,

That's why life on the streets is like a trifular beat,

It'll echo in ya head till you're dead on the concrete. (Life in the

Streets, Track \#11)

The most amusing statement comes in the chorus: "Life in the streets is not easy" (Life in the Streets, Track \#11). How would Marky Mark know? He was not from Boston proper, but rather a Dorchester suburban neighborhood. Although Mark did choose to drop out of high school and was convicted of minor criminal offenses, his class background is not rooted in an impoverished urban space. He does not personally know what it is like to make "someone's blood spill." His older brother Donnie from New Kids on the Block fame was a millionaire by the age of 13, which allowed for a fairly nice living situation. If anything, Mark was a proud and rebellious youth. His credibility further waned when he decided to model underwear for Calvin Klein and become a full time actor starring in such movies as Boogie Nights. Armond White comments, "At the moment Marky Mark disgraced his rap credibility by selling it out to a racist Calvin Klein ad, he released his best record" (208). Ultimately, Mark was not able to successfully mimic the urban lower class space of rap without losing himself in the process. He was blinded by his success and decided modeling and acting were more important than rapping, which he gave up in the mid-90's. His blatant creation of a horrific ghetto past and propensity to value elitist fashion work over rap proves that Mark lost sight of who he truly was in search of movie stardom and the all mighty dollar. The price of such an existence is a decline in album sales and a label of inauthentic.

\subsection{Kid Rock and the Beastie Boys}

Although Vanilla Ice and Marky Mark have shown us that self-absorbing and blatantly arrogant attempts to mimic lower class urban culture will surely render a rapper inauthentic, Kid Rock and the Beastie Boys have been able to gain hip-hop credibility without directly hailing lower or working class spaces. They achieved this through identifying with a black underclass space while respecting the art of rap and the hip-hop community. The Beastie Boys, or "Beasties," a white rap trio out of New York City, prove this. The Beasties formed in New York City in 1981. The group was composed of three Jewish teenagers, all of whom were from either upper-middle class or upper class backgrounds. In Angus Batey's biography of the group entitled, Rhyming and Stealing: A History of the Beastie Boys, he reveals the Beasties had little to complain about economically. Michael Diamond (Mike-D) was the son of art dealer parents, Adam Yauch (MCA) was the son of an architect, and Adam Horovitz (Ad-Rock) claimed famous playwright Israel Horovitz as his father (14-15). Although the 
Beasties grew up in the secure confines of middle to upper class America, they were able to create a humorous kind of urban centered rap that won a badge of legitimacy according to the developing hip-hop community (Forman 61). The Beasties did in fact grow up in the urban centers of Brooklyn and Manhattan, which gives them a spatial credibility pursuant to rap's roots in New York. Throughout their youth they surrounded themselves with black culture and rap artists. They produced early albums in some of the most run down sections of the Bronx and went to high school in predominantly black neighborhoods. This gave them the spatial and cultural credibility to sustain their careers. Murray Forman relates, "In other cases, the legitimacy of the white New York rappers the Beastie Boys...is located in their documented connections with the black youth culture of the urban boroughs, housing projects, or high schools where they visited regularly or were raised and educated" (61). So although they were not lower class subjects, the Beastie Boys were urban natives who surrounded themselves with lower class black culture and individuals. They were spatially authentic which linked them to class authenticity. They shared the same graffiti soaked trains along with the underclass New York youth (Batey 59). The class value of actually dwelling in and being thoroughly immersed in the urban spaces of New York linked the Beasties to the space of rap's origin. In addition, the Beasties made no outrageous claims in lyrics or interviews of being from the ghetto or having to kill in order to stay alive. They did not lose themselves in the rap game. In fact, they predominantly steered clear of talking about personal class signifiers or race in their music. Instead, they created rap that was humorous and respectful of rap's roots. Their well-known connection to urban New York ghetto culture sealed their authenticity and allowed them to be themselves on stage and elsewhere. As Batey relates, the Beasties would not lose sight of who they really were and what they came from. They were true to their own personal styles and beliefs. They wore T-shirts, baseball caps, and jeans instead of leather and gold chains which was standard rapper attire at the time (66). In the sense that the Beastie Boys were honestly affiliated with urban ghetto space and made no arrogant self-denying claims of actually being ghetto- raised products, they were and continue to be authentic rappers. Kid Rock would gain authenticity in the same capacity.

Rock-rapper Kid Rock is not directly from a lower class family, but you would not know that from his lyrics. Nearly every song he has written refers to a sublime white trash existence. With songs like "Cowboy" and "Born 2 be a Hick," Kid Rock is clear in his glorification of a rural lower class culture that is not inherently his. In "Born 2 be a Hick" off of The History of Rock, he declares,

Mamma she left me and my papa was a trucker,

Out on the highway we loved to roll,

He never made me go to school,

I never begged to go,

I was a low class livin raised out in the sticks,

I was born to be a hick.

I'm a shotgun tokin,

I'm a John Deere drivin,

I'm a hick. (2000, Atlantic)

Despite these claims, Cynthia Fuchs dispels the idea that Kid Rock is authentic white trash 
in an article she wrote for Pop Matters magazine. She writes, "So what if he's not really "trailer trash," hailing from Romeo, Michigan, a middle-class Detroit suburb where his father had a car dealership" (1). Kid's immediate upbringing was technically not lower class, but like the Beastie Boys, he was connected to a lower class space that established his credibility. Although his immediate small neighborhood was mostly middle-class, there were many near-by working-class families and ghettos in Romeo, Michigan. Specifically, Kid readily immersed himself in the hip-hop culture of the near-by predominantly black Mt. Clemens housing projects to sharpen his disc-jockey skills and learn break dance techniques. He practically lived with many of his black friends in Mt. Clemens he was there so often. He called this underclass black part of town "hick-town" (Rolling Stone.com). Kid had always loved hip-hop, especially Run DMC and Whodini, so the projects were a place for him to affirm his love. After gaining a strong reputation as a hip hop DJ in Mt. Clemens, Kid moved to New York City and quickly made friends with many local rappers and by the age of 18 landed a spot on tour with popular black rappers Ice-Cube and Too Short (Rolling Stone.com). Kid's connection to the urban rap scene of New York and the rural lower-class "hick" space of suburban Detroit, allowed him to progress as a credible hip-hop artist. His lyrics do not detract from this authenticity. Although he spouts about being a true-bred hick, it is clear that his lyrics are not intended to be taken literally or arrogantly. Armond White remarks, "Instead of meanness, Kid Rock raps brattiness, spite rather than arrogance... It's plain that this is not a work of rockist privilege but of true, wide, and deep hip hop sophistication" (204). The comical aspect of his art is not meant to maliciously exploit or demean lower class culture. It is merely humor built upon stereotypes. After all, how can we take him seriously when he says, "See I love to spend my days just a squirrel hunter, go see my cousin Ellie May and get some good lovin ("Born 2 be a Hick"). Kid's exaggerated humor, however, is rooted in an actual relation to a "hick-oriented" lower class space in Romeo, Michigan, which establishes his authenticity (Forman 61-62). He does not lose himself in the process of his art since he is not making any serious claims that contradict who he is or where he has come from.

\section{Conclusion}

In conclusion, this article has shown that class has emerged as the premier indicator of authenticity in the white rap genre, and generally throughout rap. With the explosion of white rap acts starting in the early 90's and continuing through the early $21^{\text {st }}$ century, the means by which rap authenticity is measured have been permanently renegotiated. Before the emergence of white rappers, race was the primary signifier of rapper authenticity. This made sense since rap itself was an art form that originated in the ghettos of the Bronx, where blackness was conflated with lower class living and overall poverty. Since white rappers obviously cannot present themselves as physically black, a new standard needed to emerge or else all white rappers would be considered inauthentic novelties. The former scenario won out with class coming forth as the new indicator of rap credibility, which is logical since every human, regardless of race, has the potential to belong to a certain class bracket. Class is an objective criterion that can be tied to the origins of rap. Since rap emerged out of a distinctly lower class urban space, all rappers would need to either directly hail from or successfully mimic this space in order to be deemed authentic. By "successfully mimic" I 
mean a rapper must be able to make a claim to such a class-based space without losing sight of who he honestly is or where he honestly comes from physically and economically. Eminem has proved that a white rapper coming from actual urban poverty is deserving of an authentic label. The movie 8-Mile has shown us that a black rapper without lower class roots is bound to be rendered speechless and insignificant. Bubba Sparxxx has shown us that the lower class can be represented outside of city boundaries and not exclude a rapper from being authentic. The disgraceful case of Vanilla Ice illustrates how a blatant liar and arrogant usurper of legitimate lower class status is quickly dismissed from all possibility of being credible. To a lesser extent, Marky Mark reinforces this point. Kid Rock and the Beastie Boys are examples of white rappers who were not actually bred in lower or working classes, but have been established as credible through their legitimate partial associations with a lower class space and culture. Neither of these artists have lost sight of themselves or compromised their true realities in connecting to a lower-class space. Together, all these white rap acts have managed to remain "true to the game" while changing the rules of how authentic rap is determined in the process.

\section{Acknowledgement}

This research was inspired by Dr. Pamela Fox at Georgetown University.

\section{References}

Batey, A. (1998). Rhyming and stealing: A history of the beastie boys. London: Independent Music Press.

Bubba Sparxxx Biography. Much Music.com Retrieved from http://www.muchmusic.com/music/artists/bio.asp?artist=98.

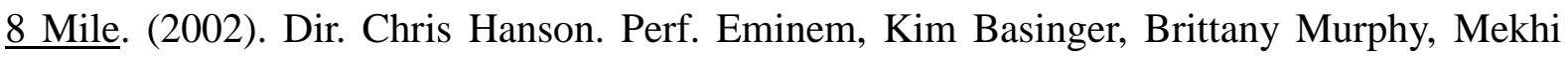
Phifer. Universal.

Forman, M. (2002) The hood comes first: Race, space, and place in rap and hip-hop. Middletown: Wesleyan University Press.

Fuchs, C. Pimp of the nation. PopMatters.com On-line Magazine. Retrieved from http://www.popmatters.com/music/videos/k/kidrock-forever.html.

Huxley, M. (2000). Eminem: Crossing the line. New York: St. Martin's Griffin.

Kid Rock. (2000) The history of rock. Atlantic.

Kid Rock Biography. $\quad$ Rolling Stone.com. Retrieved from http://www.kidrock.com/bio/kid_Rollingstone.php.

Perkins, W.E. (1996). The rap attack. In Droppin'Science: Critical Essays on Rap Music and Hip-Hop Culture. Philadelphia: Temple University Press, 1-45.

Rose, T. (1994) Black noise: Rap music and black culture in contemporary America. Middletown: Wesleyan University Press.

Snow. (1993). 12 inches of snow. Atlantic.

White, A. (1996). Who wants to see ten niggers play basketball? Ed. William Eric Perkins. Droppin'Science: Critical Essays on Rap Music and Hip-Hop Culture. Philadelphia: Temple University Press, 192-208. 